\title{
THE FERROCYANIDE CLEARANCE IN MAN
}

\author{
By BENJAMIN F. MILLER 1 AND ALEXANDER WINKLER 2 \\ (From the Hospital of the Rockefeller Institute for Medical Research, New York, the \\ Department of Internal Medicine, Yale University School of Medicine, and the \\ Medical Service of the New Haven Hospital, New Haven)
}

(Received for publication April 25, 1936)

There is evidence that sodium ferrocyanide is excreted by the kidney of the rabbit and the dog entirely by a process of glomerular filtration. This has been demonstrated for the rabbit (Gersh and Stieglitz (1934)), and in the dog (Gersh, personal communication (1935)) by histochemical methods. These observations were supported by Van Slyke, Hiller and Miller (1935) who found additional evidence from renal clearance and extraction percentage studies for the supposition that in the dog and rabbit the sodium ferrocyanide clearance is a measure of the true glomerular filtrate.

Stieglitz and Knight, in 1934, suggested the use of sodium ferrocyanide for testing renal function in man, particularly as a measure of glomerular filtration. In their test the rate of urinary excretion was observed after intravenous injection of a very small amount of ferrocyanide $(0.3 \mathrm{gram})$, and this rate was considered to be proportional to the glomerular filtrate and independent of tubular action. Renal clearances were not obtained, presumably because no method was available at the time for determination of very small quantities of plasma ferrocyanide which occur in the plasma after injection of amounts of the substance which were considered entirely safe for man.

With the development of sensitive methods for quantitative estimation of ferrocyanide in serum and plasma, it has become possible to obtain renal clearance values for this substance in man, and thereby to study its mode of excretion more adequately. Such observations are here reported.

\section{EXPERIMENTAL TECHNIQUE AND METHODS}

The subjects were volunteers from a general medical ward, all convalescents from non-renal diseases, and varying in age from 16 to 69 years. In each case (except in Experiment 3) comparative ferrocyanide and creatinine clearances were determined for two successive periods

1 National Research Council Fellow in Medicine.

2 Alexander Brown Coxe Fellow. each averaging 46 minutes in length. Urea clearances were obtained in all but one of the experiments. Seven studies, giving 13 comparative creatinine and ferrocyanide clearances and 11 urea clearance ratios, were carried out before the experiments had to be discontinued because of the toxic reactions described later.

The experiments were performed as follows: All subjects were deprived of breakfast. At 6:00 a.m. they were given $200 \mathrm{cc}$. of $\mathrm{H}_{2} \mathrm{O}$, followed by the oral administration of 15 grams of creatinine in $400 \mathrm{cc}$. of $\mathrm{H}_{2} \mathrm{O}$ at 7:00 a.m., with an additional 200 cc. of $\mathrm{H}_{2} \mathrm{O}$ at 8:00 a.m. Thereafter fluids were given frequently until the end of the experiments. Between 8:30 and 9:00 a.m. sodium ferrocyanide ${ }^{3}$ in aqueous solution was injected intravenously, and the first period started 10 to 20 minutes later. Blood was drawn as nearly as possible at the mid-point of each period. Urine was obtained by having the subjects void directly into a graduated container. Catheterization was unnecessary because adequate volumes of urine and fairly good timing of the periods could be obtained by the persistent forcing of fluids.

Serum, obtained by centrifugation of the clotted blood samples, was analyzed for ferrocyanide, creatinine and urea. Ferrocyanide was determined by the method of Miller and Hiller (unpublished).4 Serum containing ferrocyanide equivalent to at least $0.1 \mathrm{mgm}$. of $\mathrm{HCN}$ is heated at $100^{\circ} \mathrm{C}$. with half-normal tartaric acid. The liberated $\mathrm{HCN}$ is drawn over into $0.1 \mathrm{~N}$ sodium hydroxide by means of a continuous current of purified air, and the $\mathrm{NaCN}$ produced is titrated with 0.002 or $0.004 N \mathrm{AgNO}_{3}$ in the presence of $\mathrm{KI}$. This method, when performed in a suitable all-glass apparatus, determines ferrocyanide with an error of less than 2 per cent.

Ferrocyanide in the urine was estimated by the technique of Van Slyke, Hiller, and Miller (1935). Plasma creatinine was analyzed by a slight modification of the method of Folin and Wu (1919) using a Hastings' compensating colorimeter; and urine creatinine by the method of Folin (1914).

The urea clearances were obtained by the technique described by Van Slyke, Page, Hiller and Kirk (1935).

All clearances were calculated as $U V / B$, where $U$ is urine concentration, $B$ is serum concentration, and $V$ is

\footnotetext{
3 We are indebted to the Abbott Laboratories, Chicago, Illinois, for a supply of sterile sodium ferrocyanide.

4 A similar method for determination of somewhat larger amounts of ferrocyanide has been recently described by Edwards and Langley (1936).
} 
the flow of urine in cc. per minute. The absolute clearance values, uncorrected for surface area, are reported.

\section{RESULTS AND DISCUSSION}

Data on the serum concentrations of ferrocyanide, creatinine and urea and the absolute values of their clearances are shown in Table I. The ratios of the simultaneous clearances are given in Figure 1.

These observations give 2.34 as the average creatinine: ferrocyanide clearance ratio. This is in striking contrast to the results of Van Slyke, Hiller, and Miller (1935) on dogs, in which the ratio was consistently in the neighborhood of unity. The contrast between man and dog is further emphasized by the fact that the ratio of the ferrocyanide to the urea clearance in dogs was found by the above authors to average 1.74; the value for this ratio in our 11 observations in man was 1.20. Thus in man the ferrocyanide and urea clearances appear to be of the same order of mag-
TABLE I

Simultaneous clearances of creatinine, ferrocyanide and urea

\begin{tabular}{|c|c|c|c|c|c|c|c|}
\hline \multirow{2}{*}{$\begin{array}{c}\text { Experi- } \\
\text { ment } \\
\text { number }\end{array}$} & \multirow{2}{*}{$\begin{array}{l}\text { Approximato } \\
\text { amount of } \\
\text { anhydrous } \\
\text { Narfe(CN)。 } \\
\text { injected }\end{array}$} & \multicolumn{3}{|c|}{$\begin{array}{l}\text { Plasma concentration } \\
\text { (mom. per } 100 \mathrm{cc} . \\
\text { serum) }\end{array}$} & \multicolumn{3}{|c|}{ Clearances $\frac{U V}{B}$} \\
\hline & & $\begin{array}{c}\text { Creat- } \\
\text { inine }\end{array}$ & $\begin{array}{c}\text { Ferro- } \\
\text { cyanide }\end{array}$ & Urea & $\begin{array}{c}\text { Creat- } \\
\text { inine }\end{array}$ & \begin{tabular}{|}
$\begin{array}{c}\text { Ferro- } \\
\text { cyanide }\end{array}$ \\
\end{tabular} & Urea \\
\hline $\begin{array}{c}1 \\
\sigma^{7} 69 \text { years }\end{array}$ & $\begin{array}{l}\text { grams } \\
0.55\end{array}$ & $\begin{array}{l}19.2 \\
18.6\end{array}$ & $\begin{array}{l}4.83 \\
3.30\end{array}$ & & $\begin{array}{l}121 \\
103\end{array}$ & $\begin{array}{l}52.8 \\
58.0\end{array}$ & \\
\hline$\sigma^{7} 39$ years & 0.80 & $\begin{array}{l}9.7 \\
8.4\end{array}$ & $\begin{array}{l}5.32 \\
3.29\end{array}$ & $\begin{array}{l}6.8 \\
7.1\end{array}$ & $\begin{array}{l}295 \\
252\end{array}$ & $\begin{array}{r}103.0 \\
88.0\end{array}$ & $\begin{array}{r}101.0 \\
98.5\end{array}$ \\
\hline $\begin{array}{c}3 \\
\text { or } 57 \text { years }\end{array}$ & 1.4 & 15.5 & 7.8 & 21.7 & 172 & 62.8 & 34.3 \\
\hline o' 16 years & 1.9 & $\begin{array}{l}17.0 \\
14.7\end{array}$ & $\begin{array}{c}10.5 \\
0.05\end{array}$ & 8.4 & $\begin{array}{l}220 \\
204\end{array}$ & $\begin{array}{l}72.5 \\
55.2\end{array}$ & $\begin{array}{l}89.5 \\
97.3\end{array}$ \\
\hline \& 59 years & 2.8 & $\begin{array}{l}22.3 \\
21.1\end{array}$ & $\begin{array}{l}17.0 \\
13.7\end{array}$ & $\begin{array}{l}17.0 \\
16.2\end{array}$ & 106 & $\begin{array}{l}37.2 \\
39.0\end{array}$ & $\begin{array}{l}31.0 \\
36.4\end{array}$ \\
\hline$\sigma^{6} 57$ years & $\begin{array}{l}2.8 \text { before Period I } \\
2.8 \text { before Period II }\end{array}$ & $\begin{array}{l}20.1 \\
12.2\end{array}$ & $\begin{array}{l}21.1 \\
23.5\end{array}$ & $\begin{array}{l}18.4 \\
14.8 \\
\end{array}$ & $\begin{array}{c}95.5 \\
102\end{array}$ & $\begin{array}{l}68.8 \\
68.0\end{array}$ & $\begin{array}{l}33.3 \\
46.4\end{array}$ \\
\hline$\sigma^{7} 57^{7}$ years & 6.2 & $\begin{array}{l}21.3 \\
19.5\end{array}$ & $\begin{array}{l}43.6 \\
34.8\end{array}$ & 26.4 & $\begin{array}{l}54.3 \\
65.0\end{array}$ & $\begin{array}{l}32.9 \\
39.4\end{array}$ & $\begin{array}{l}26.6 \\
39.4\end{array}$ \\
\hline
\end{tabular}

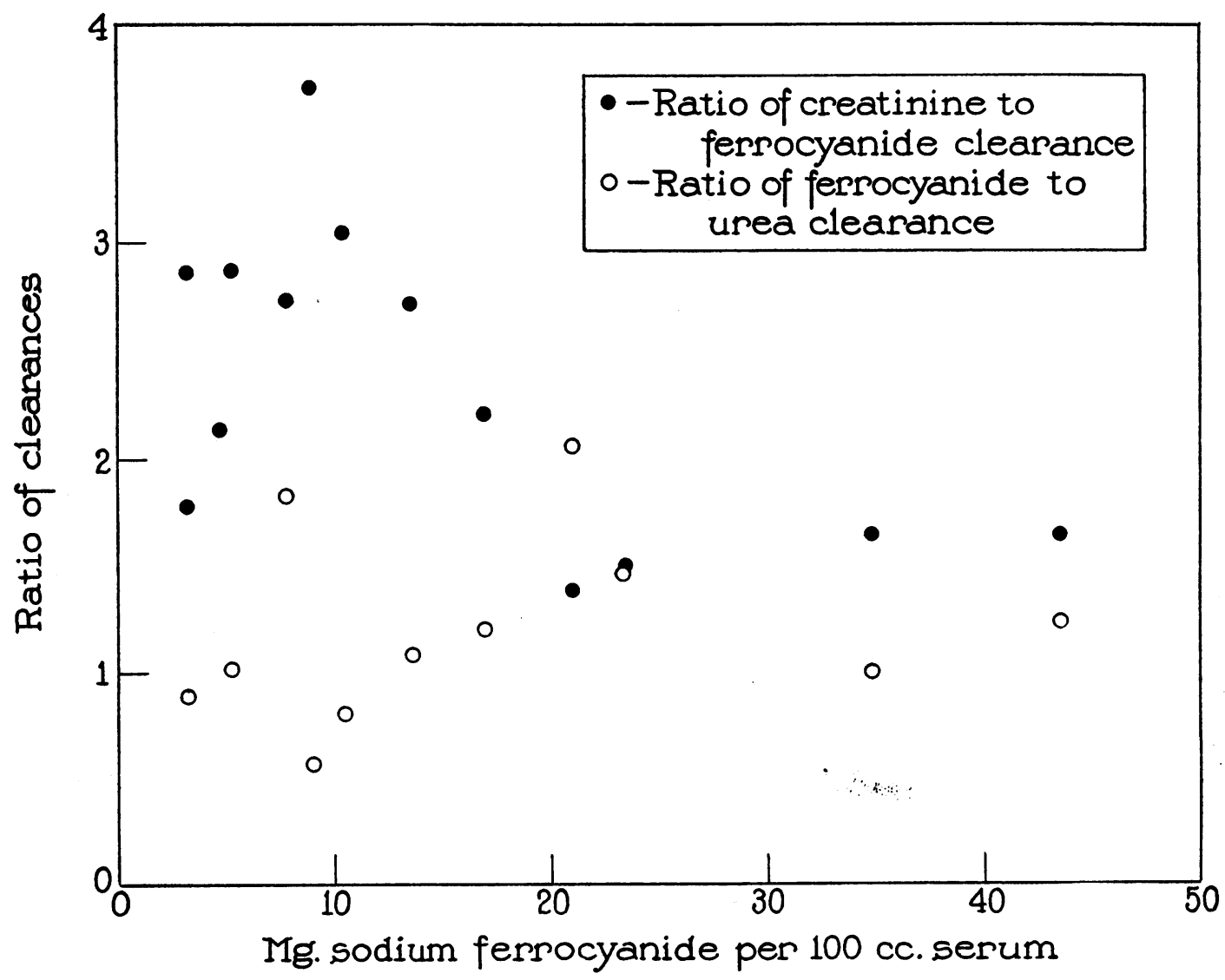

Fig. 1. Clearance Ratios of Creatinine: Ferrocyanide and Ferrocyanide: Urea 
nitude, while in the dog the ferrocyanide clearance is much the greater.

Shannon (1935) and Shannon and Smith (1935) have determined the inulin clearance in man, and adduce reasons for believing that the inulin clearance approximates the glomerular filtrate. Shannon finds that the creatinine clearance exceeds the inulin clearance, and suggests that the creatinine clearance is higher due to some tubular secretion of creatinine in addition to its excretion by glomerular filtration. From Shannon's creatinine: inulin clearance ratio in man and our creatinine: ferrocyanide ratio we can calculate a hypothetical inulin: ferrocyanide clearance ratio as

$\frac{\text { Inulin clearance }}{\text { Ferrocyanide clearance }}=$
$\begin{aligned} \frac{\text { Inulin clearance }}{\text { Creatinine clearance }} \times \frac{\text { Creatinine clearance }}{\text { Ferrocyanide clearance }} \\ \quad=0.72 \times 2.34=1.68 .\end{aligned}$

If inulin clearance represents glomerular filtrate in man, the ferrocyanide clearance averages only $1 / 1.68$, or 60 per cent of the glomerular filtrate. Explanation based on the filtration-reabsorption theory could attribute the lower ferrocyanide clearance either to failure, by 40 per cent, of plasma ferrocyanide filtration to equal plasma water filtration, or to tubular reabsorption of 40 per cent of the completely filtered ferrocyanide. The latter explanation seems the more probable. Evidence that ferrocyanide has no difficulty in diffusing through vascular membranes is provided by the observation that the volume of distribution of the injected ferrocyanide in our experiments approximated 24 per cent of the body weight. A similar value had been found by Lavietes, Bourdillon and Klinghoffer (1936) for sucrose, sulfate and sulphocyanate, and was interpreted by them as representing the interstitial fluid volume. It appears that ferrocyanide diffuses readily into the interstitial fluids, but does not enter the majority of the body cells. If any considerable proportion of the ferrocyanide were bound to the serum proteins, or for other reasons were not truly diffusible, a much smaller apparent volume of distribution might be expected. Also, if ferrocyanide passes vascular membranes readily, it may presumably be filtered with ease through the glomerular membrane in the human. It appears that, whereas in the dog, ferrocyanide is excreted like inulin by glomerular filtration without tubular reabsorption, in man, it is excreted like urea, with about 40 per cent reabsorption.

We are inclined to interpret our results as representing a species difference between dog and man. It should, however, be pointed out that the levels of serum ferrocyanide in our human experiments are distinctly lower than those in the dog experiments of Van Slyke, Hiller, and Miller (1935), and that in this respect the clearances obtained in their experiments were obtained under conditions differing from ours.

The probability that tubular reabsorption of ferrocyanide occurs in man is strengthened by certain renal irritative reactions described below.

\section{Toxic action of ferrocyanide on the human kidney}

Shortly after these experiments were performed, it was noted that the subjects were showing evidences of renal irritation. The two patients who received the smallest amounts of sodium ferrocyanide, equal to two and three times the routine dosage used by Stieglitz and Knight, had been discharged from the hospital and could not be followed further. However, one subject who received five times the routine amount developed a marked albuminuria, accompanied by numerous granular casts, white cells and epithelial cells, and rare red blood cells. The red cells disappeared almost at once, and the albuminuria and leukocytes gradually disappeared during the subsequent two weeks. No decrease in renal function, as measured by the urea clearance test, could be detected in this patient 5 days after the injection of the ferrocyanide, even though the urinary changes were very marked at that time. The other subjects also showed for several days essentially the same pathological changes in the urine to a somewhat lesser degree, even though they had received larger amounts of ferrocyanide. In no case was any systemic reaction noted during or after the injections.

The occurrence of these nephrotoxic reactions is in sharp contrast to their absence after injection of very much larger quantities of sodium ferrocyanide into rabbits by Gersh and Stieglitz (1934) and into dogs by Van Slyke, Hiller, and Miller (1935). The toxic action on the human kidney 
is perhaps due to the difference in its physiological behavior toward ferrocyanide. As shown above, a considerable portion of the ferrocyanide is apparently reabsorbed by the tubular cells. During passage through these cells, the ferrocyanide may well induce toxic effects because of its strong reducing action, and the degenerative changes may become evident later in the urinary changes described above. The urinary findings are consistent with a mild, transient nephrosis caused by chemical toxins. In the dog kidney, where no tubular absorption occurs, no toxic action is produced by the excretion of the ferrocyanide.

In fairness to Stieglitz and Knight (1934), it should be stated that our experiments required larger dosages of sodium ferrocyanide than are advised for their renal function test. However, the very marked nephrotoxic action found after injection of $20 \mathrm{mgm}$. per kilogram of body weight suggests the possibility of harmful reactions with the smaller dosage, especially in patients with renal insufficiency.

\section{SUM M ARY}

The sodium ferrocyanide clearance in man is of the same order of magnitude as the urea clearance, and usually less than half the creatinine clearance. The results, considered with those of Shannon on excretion of creatinine and inulin by man, suggest that ferrocyanide is excreted in the human kidney, like urea, by a process of filtration and reabsorption; and that, on the average, about 40 per cent of the ferrocyanide filtered through the glomeruli is reabsorbed in the tubules.

The excretion of ferrocyanide by man differs sharply from excretion by the dog, which has been shown by Van Slyke, Hiller, and Miller to occur without evidence of reabsorption. Our results with ferrocyanide, like those of Shannon with creatinine, indicate marked differences in excretory mechanism between dog and man, with regard to these two substances.

Sodium ferrocyanide exerts a definitely toxic action on the human kidney.

The authors are indebted to Drs. Donald D. Van Slyke and John P. Peters for their kind cooperation.

\section{BIBLIOGRAPHY}

Edwards, J. G., and Langley, W. D., The microdetermination of ferrocyanide in muscle and urine. J. Biol. Chem., 1936, 112, 469.

Folin, O., On the determination of creatinine and creatine in urine. J. Biol. Chem., 1914, 17, 469.

Folin, O., and Wu, H., A system of blood analysis. J. Biol. Chem., 1919, 38, 81.

Gersh, I., and Stieglitz, E. J., Histochemical studies on the mammalian kidney. I. The glomerular elimination of ferrocyanide in the rabbit, and some related problems. Anat. Rec., 1934, 58, 349.

Lavietes, P. H., Bourdillon, J., and Klinghoffer, K. A., The volume of the extracellular fluids of the body. J. Clin. Invest., 1936, 15, 261.

Shannon, J. A., The renal excretion of creatinine in man. J. Clin. Invest., 1935, 14, 403.

Shannon, J. A., and Smith, H. W., The excretion of inulin, xylose and urea by normal and phlorizinized man. J. Clin. Invest., 1935, 14, 393.

Stieglitz, E. J., and Knight, A. A., Sodium ferrocyanide as a clinical test of glomerular efficiency. J. A. M. A., 1934, 103, 1760.

Van Slyke, D. D., Hiller, A., and Miller, B. F., The clearance, extraction percentage and estimated filtration of sodium ferrocyanide in the mammalian kidney. Comparison with inulin, creatinine and urea. Am. J. Physiol., 1935, 113, 611.

Van Slyke, D. D., Page, I. H., Hiller, A., and Kirk, E., Studies of urea excretion. IX. Comparison of urea clearances calculated from the excretion of urea, of urea plus ammonia, and of nitrogen determinable by hypobromite. J. Clin. Invest., 1935, 14, 901. 